\title{
FURTHER STUDIES ON THE SYSTEMATICS OF AUSTRALIAN DIPLURINAE (CHELICERATA: MYGALOMORPHAE: DIPLURIDAE): DESCRIPTION OF THE MALE OF TROGLODIPLURA LOWRYI, WITH NOTES ON ITS AFFINITIES.
}

\author{
By Barbara York MaIN ${ }^{1}$ and M. R. GRaY ${ }^{2}$
}

\section{INTRODUCTION}

This paper ${ }^{3}$ describes a recently discovered male specimen of the troglobitic Troglodiplura lowryi Main and attempts to place the genus in the taxonomic perspective of other Australian diplurines.

Troglodiplura lowryi was described by Main (1969) from fragments of a specimen of indeterminate sex collected by $J$. and $D$. Lowry from Roach's Rest Cave $43.5 \mathrm{~km} \mathrm{NE}$ of Madura on the Nullarbor Plain, Western Australia. Because only dead arthropods and no living material of any taxa were known from Roach's Rest Cave, it was unknown whether Troglodiplura lowryi was an extant species. It is therefore of considerable interest that in addition to the collection of a dead male specimen, a living specimen has also been observed by A. D. Davey in an unconnected cave north of the Bight in South Australia.

\section{OTHER RECORDS OF TROGLOBITIC MYGALOMORPHS}

Although several other mygalomorphs are known to inhabit caves in Australia, T. lowryi is the only fully troglobitic species, i.e. completely cave-adapted species. Prior to Main (1969) recording $T$. lowryi only two other troglobitic mygalomorphs had been recorded from elsewhere: a diplurid, Accola caeca Simon from the Philippines (Simon, 1892), which species is now included in Masteria

'Department of Zoology, University of Western Australia, Nedlands, Western Australia, 6009.

2Arachnology Department, The Australian Museum, College Street, Sydney, N.S.W., Australia, 2000.

${ }^{3}$ This paper is the eighth in a series by one of us (BYM) dealing solely with the systematics of Australian Diplurinae. Earlier publications in the series and others in which new diplurine taxa were described are listed in Main (1983b).

Revised manuscript received by the editor January' 8, 1985 
(Raven, 1979), and a barychelid, Troglothele caeca Fage from Cuba (Fage, 1929). Since then Gertsch $(1971 ; 1973 ; 1982)$ has recorded 10 additional species of blind or near blind cavernicolous mygalomorphs from the Americas. This brings to about 8 the total of known blind, and an additional five or more near blind caveadapted mygalomorphs in the world.

\section{Affinities of Troglodiplura lowryi with other Australian DipluRINAE}

At the time Troglodiplura was described the Australian Diplurinae included six other genera: Aname Koch, Ixamatus Simon, Chenistonia Hogg, Dekana Hogg, Sungenia Rainbow \& Pulleine and Stanwellia Rainbow \& Pulleine. One species had also been attributed to the extra-limital genus Brachythele (Ausserer, 1875). Subsequent descriptions of new genera, and reviews of the Diplurinae (Main and Mascord, 1971; Main, 1972; 1975; 1983b; Raven, 1981; 1984) bring the total of accepted genera to eleven: Aname, Ixamatus, Chenistonia [synonymised with Aname (Raven, 1981; 1984) but recognized as distinct by Main (1982a,b, 1983b and here)], Stanwellia, Troglodiplura Main, Kiama Main and Mascord [doubtful placement in the Diplurinae (Main, 1981, p. 869)], Teyl Main, Xamiatus Raven, Kwonkan Main, Merredinia Main and Namea Raven. However, the affinities of Troglodiplura have remained unclear. It is now apparent that one character is shared with several other genera. This is the absence of cuspules from the maxillary heel (see Main, 1969, fig. 1D, and figs 1,3,5,6 here). This arrangement is characteristic of the following genera: Ixamatus and Xamiatus (Raven, 1981), Kiama (Main and Mascord, 1971, see fig. 2) and in part Stanwellia. Genera constituting the Anamini as delimited by Main (1983b) and the Teylini which contains the nominal genus Teyl (see Main, 1982c) and several undescribed genera (Main, 1983b) and Namea (herein included) all have the cuspules spread over the inner side of the maxillae including the modified, projecting heel. [The only exception in these groups is Aname kirrama Raven (Raven, 1984) which has the maxillary cuspules confined to the anterior ental region]. On this character then Troglodiplura has an affinity with Ixamatus, Xamiatus, Kiama and in part Stanwellia. Closer affinity with Ixamatus and Xamiatus is ruled out primarily due to the low tarsal organ in Troglodiplura (that is, not rod-like); with Stanwellia 
because of the indented labium and absence of labial cusps in Troglodiplura; with Kiama due to the different configuration of the sternal sigilla and the U-shaped fovea in Kiama.

Collection of a male of Troglodiplura initially promised resolution of the relationships of the genus. Criteria used to distinguish male Australian diplurines are predominantly: configuration of the bulb and embolus, spination of the palpal tibia, armature of the first tibia and modifications of the first metatarsus. The Anamini (exclusive of Merredinia) comprise the only genera previously described and undescribed (Main in preparation), which bear a pronounced tibial spur on the foreleg, e.g. Aname, Chenistonia, Kwonkan. Some of the named Teylini (e.g. Namea which is here added to the tribe) may bear heavy spines that are sometimes raised on low spurlike protuberances on the first tibia, but which are never comparable to the single-spined spur of typical Anamini. Troglodiplura as described below is shown to have a large tibial spur in the male. However, because it has an unmodified maxillary heel which lacks cuspules the genus would appear not to be closely related to the Anamini and Teylini and the development of the tibial spur is therefore considered as a convergence. Furthermore there is an undescribed genus of the Teylini (Main in press b) in which a tibial spur has clearly arisen independently.

It appears that the tibial spur has convergently evolved at least three times in Australian Diplurinae. It is even possible that it may have evolved independently in several of the Anamini. Finally, Aname kirrama which has in combination maxillary cuspules confined to the anterior ental angle of the maxilla and a pronounced tibial spur, would appear to be more closely related to Troglodiplura than to Aname. However until more specimens are known with Aname kirrama affinities, this species is not transferred to Troglodiplura. An alternative solution would be to erect another monotypic genus. A disjunct distribution of related taxa, e.g. north Queensland (Aname kirrama) and the Nullarbor Plain (Troglodiplura) is not really surprising in view of similar distributions of mygalomorph taxa. For example the Homogoninae have representatives in eastern Australian montane areas and southwestern Australia (Main 1983a; description in press a).

It now seems from the morphological features of both male and female specimens that Troglodiplura is less anomalous than pre- 
viously understood. Its main distinguishing features, e.g. lack of eyes, modified tarsi and elongated metatarsi, are associated with its cavernicolous habits. It is known that troglobitic features can evolve fairly rapidly, therefore other less adaptive characters also need to be considered in any postulated phylogeny.

An analogue of the suggested Troglodiplura and Aname kirrama affinity within the Araneomorphae is the blind Baiami mullamullangensis (Gray) from Mullamullang Cave on the Nullarbor Plain. This species was first placed in a new genus Tartarus (Gray, 1973) but later shown to have close affinity with species of Baiami distributed in southwest Australia, the Lofty Ranges in South Australia and in Victoria (Gray, 1981).

It is of biological interest that while other groups of mygalomorphs, e.g. Stanwellia and Homogoninae, which have disjunct eastwest distributions (Main 1972, 1976 1983a and in press a) have clearly not been able to persist in the intervening arid central area subsequent to the extinction of humid forested regions prevalent in the early Tertiary, Troglodiplura and some araneomorphs, e.g. Baiami Lehtinen have survived by adapting to a cavernicolous existence.

\section{Genus Troglodiplura Main}

Troglodiplura Main, 1969: 9. Type species Troglodiplura lowryi Main, by monotypy. Raven, 1981: 340.

\section{DiAgNosis}

Distinguished by the following combination of characters: absence of eyes, labium with notch-like, anterior identation, unmodified maxillae with cuspules on antero-ental angle only, dorsoventrally curved tarsi (without spines), male with pronounced tibial spur on first leg, long pear-shaped palpal bulb with tapering embolus in same axis.

Figures 1-10. Figs 1-3. Holotype $\&$ Troglodiplura low ryi, right maxilla. Figs 1 and 3 ventral aspect. Fig. 2. Antero-ectal angle. Figs 4-10. Metallotype $\hat{\sigma} T$. lowryi. Fig. 4. Carapace and chelicerae. Fig. 5. Sternal area, maxillae, labium and chelicerae. Fig. 6. Maxillary marginal area. Fig. 7. Ridges on retrolateral side of chelicera. Fig. 8. Left fang, prolateral. Fig. 9. Right tarsus IV, prolateral aspect. Fig. 10. Right tarsus IV, retrolateral view, retroclaw. Scale bars $=1.0$ $\mathrm{mm}$; figs $2,3,6,7,8,10$ not to scale. 


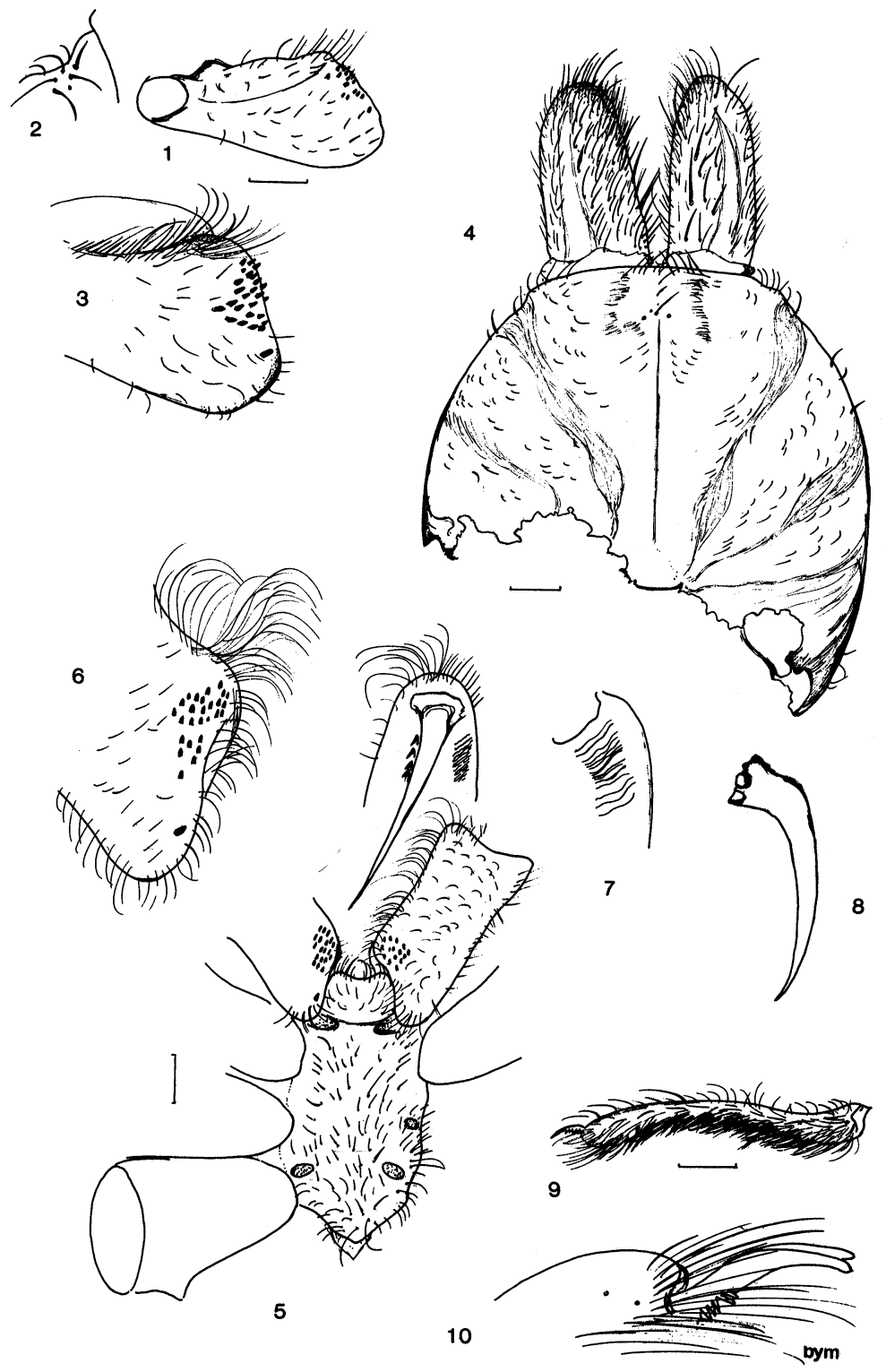


TABLE 1. Approximate leg measurements of right legs.

\begin{tabular}{rcccccc}
\hline & $\mathrm{F}$ & $\mathrm{P}$ & $\mathrm{Ti}$ & $\mathrm{Mt}$ & $\mathrm{Ta}$ & Total \\
\hline Palp & 8.1 & 3.9 & 6.7 & - & 3.6 & 22.3 \\
I & 12.3 & 5.8 & 11.3 & 14.3 & 6.7 & 50.4 \\
II & 12.1 & 5.4 & 12.1 & 14.6 & 6.2 & 50.4 \\
III & 10.7 & 4.0 & 10.2 & 14.0 & 5.0 & 43.9 \\
IV & 12.7 & $4.2(?)$ & 12.6 & 18.3 & 5.0 & $52.8+$ \\
& Width of patella I at knee = 1.6; Tibial index $=9.41$. & \\
\hline
\end{tabular}

An absence of eyes distinguishes Troglodiplura from all other Australian Diplurinae. It is further distinguished from the Anamini and Teylini by the maxillary cuspule arrangement which it shares with Ixamatus, Xamiatus, Stanwellia (in part) and Kiama. It differs from these four genera by the presence of a tibial spur in the male.

\section{Troglodiplura lowryi Main}

Figs 1-18, Table 1

Troglodiplura lowyri Main, 1969: 9-11. Holotype, indeterminate sex, WeSTERn AUSTRALia: Roaches Rest Cave, NE Madura (Western Australian Museum)

Metallotype, ô, Australia: South Australia, Nullarbor Plain, Cave NR. 6 Bore NNW of head of BIGHT, 27.v.1982 (A.D. Davey) (Australian Museum KS 13389). ["Metallotype"-as defined by Smith, 1983].

Condition of specimen poor, dismembered parts of a dried carcase, some colour still apparent as the dark reddish brown of carapace, chelicerae and tibiae and metatarsi of first legs; many bristles, hairs and spines lost, including trichobothria. Carapace and . sternum slightly distorted at margin; left posterior region of carapace missing. Abdomen absent.

Figures 11-16. Metallotype ô Troglodiplura lowryi. Fig. 11. Left palp, retrolateral aspect. Fig. 12. Bulb and embolus enlarged. Fig. 13. Left palp, prolateral aspect. Fig. 14. Left leg, retrolateral aspect tibia and metatarsus. Fig. 15. Right tarsus 1 , retrolateral aspect. Fig. 16. Right tarsus I, retrolateral aspect of retroclaw. Scale bars $=1.0 \mathrm{~mm}$; fig. 16 not to scale. 


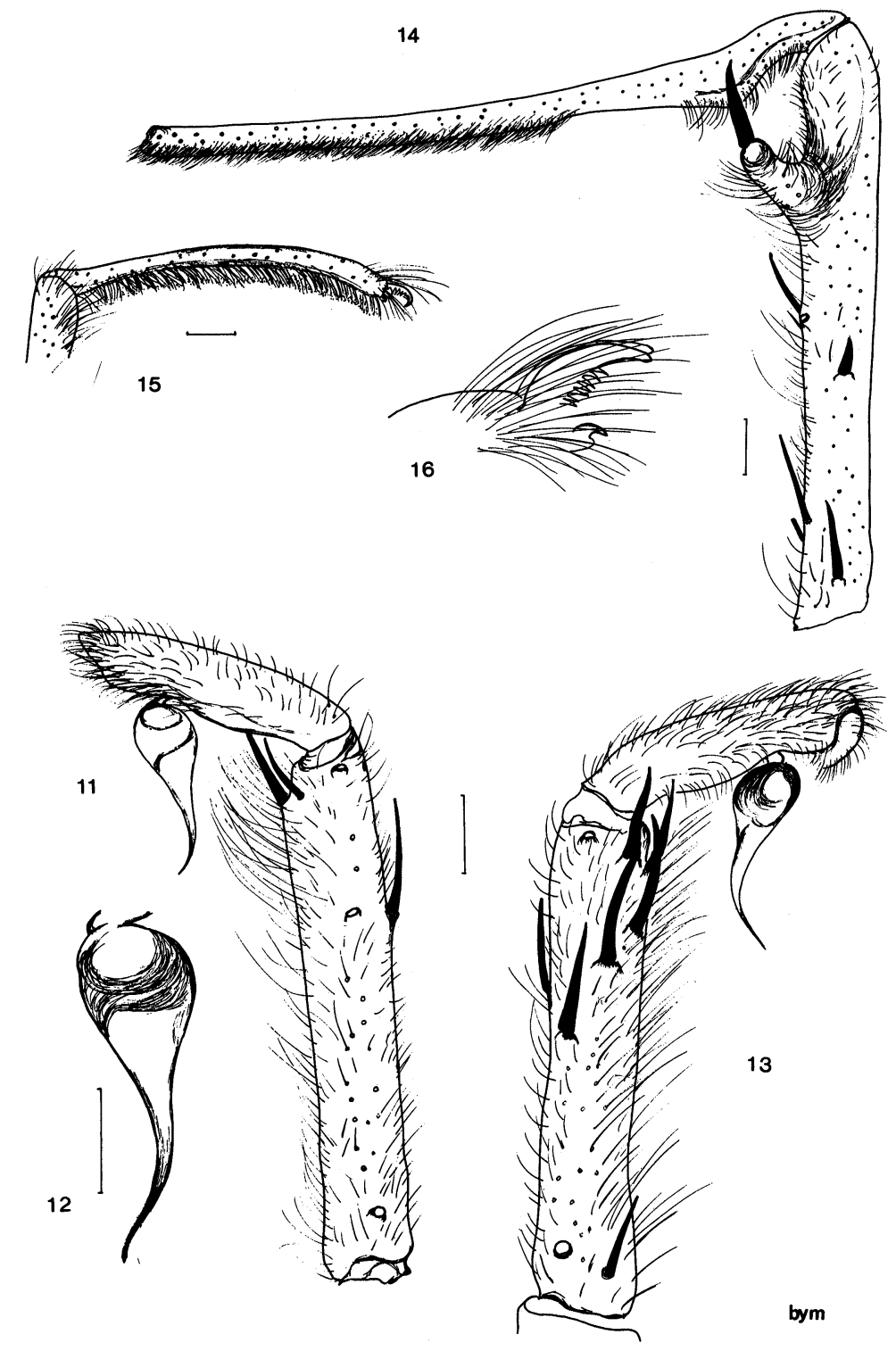


Carapace broad (9.3 $\mathrm{mm}$ wide), with cervical depressions, posteriorly damaged with left section missing; caput width 5.4. Probably glabrous in life, caput with thin scattering of golden hairs, finely granulated surface, possibly reticulated. Length from clypeus to fovea 6.5 . Fovea very slightly procurved. Eyes absent, a fine bristle and sockets of two others in "ocular area" (Fig. 4); a group of bristle on clypeal margin. Chelicerae long and narrow, dark reddishbrown, with coarse, dorsal bristles, no rastellum; transverse ridges on outer (retrolateral face). Promargin of right chelicera with 10 teeth ( 9 on left), retromargin with at least 6 small basal teeth ( 11 on left chelicera) extending distally to opposite about teeth 4 and 5 . Maxillae not indented around labium but with long angular heel obscuring it; cuspules on inner ental angle only (about 31 plus a large one on heel of right maxilla, left with about 26; some loosely attached, some detached). Labium broad and deeply indented at margin, length $1.0 \mathrm{~mm}$, width at least $1.5 \mathrm{~mm}$, without cuspules. Sternum distorted and curled under at edges, length 4.6. Sigilla separating labium divided. Posterior sigilla broad, roughly oval, well away from margin, median sigilla small, roundish, anterior pair obscured. Legs. Scopula complete on tarsi I, II and III, absent from tarsus IV, complete on metatarsus I but thin proximally, almost entire on metatarsi II, distal half only on metatarsus III, absent from metatarsus IV; tarsi with ventral median band of bristles; tarsus IV although lacking a true scopula has a dense brush of fine bristles intermixed with heavy spine-like bristles (Fig. 9).

Metatarsus I very long, ventrally depressed proximally and with pronounced "elbow" in proximal third. Tibia I with a spur, bearing a single megaspine, in apical third. Palp with long slender tibia with several heavy retro- and prolateral spines. Palpal bulb long, ovoid, with embolus arising on long axis; no demarcation between embolus and bulb (Figs 11-13).

Spines (right appendages except leg II). Approximations only. Palp, tarsus 0, tibia d 1, p 3 proximal (lost) 6 distal (lost), 7 (3 lost), patella $\mathrm{p} 1$ (lost), femur $\mathrm{p} 2$ median adpressed bristle-like spines. Leg I, tarsus 0 , metatarsus 0 (left $\mathrm{p} 1$ lost), tibia $\vee 2+$ megaspine on spur, pv 2, p 2, d 2 (left pv 2 rv 2, p 2, r 2), patella p 2 (lost) (left p 2 lost), femur $d$ 3, p 6 adpressed bristle-like spines, $r 3$ rd 1 (left $d 4$ lost), p 4 (lost), r 4 (lost). Leg II (left), metatarsus v 3 (2 lost), d 1, p 2 (lost), r 2, tibia v 1-2-2-3, p 3 (lost), r 3, patella p 2 (lost), femur d 3 or 4, rd 

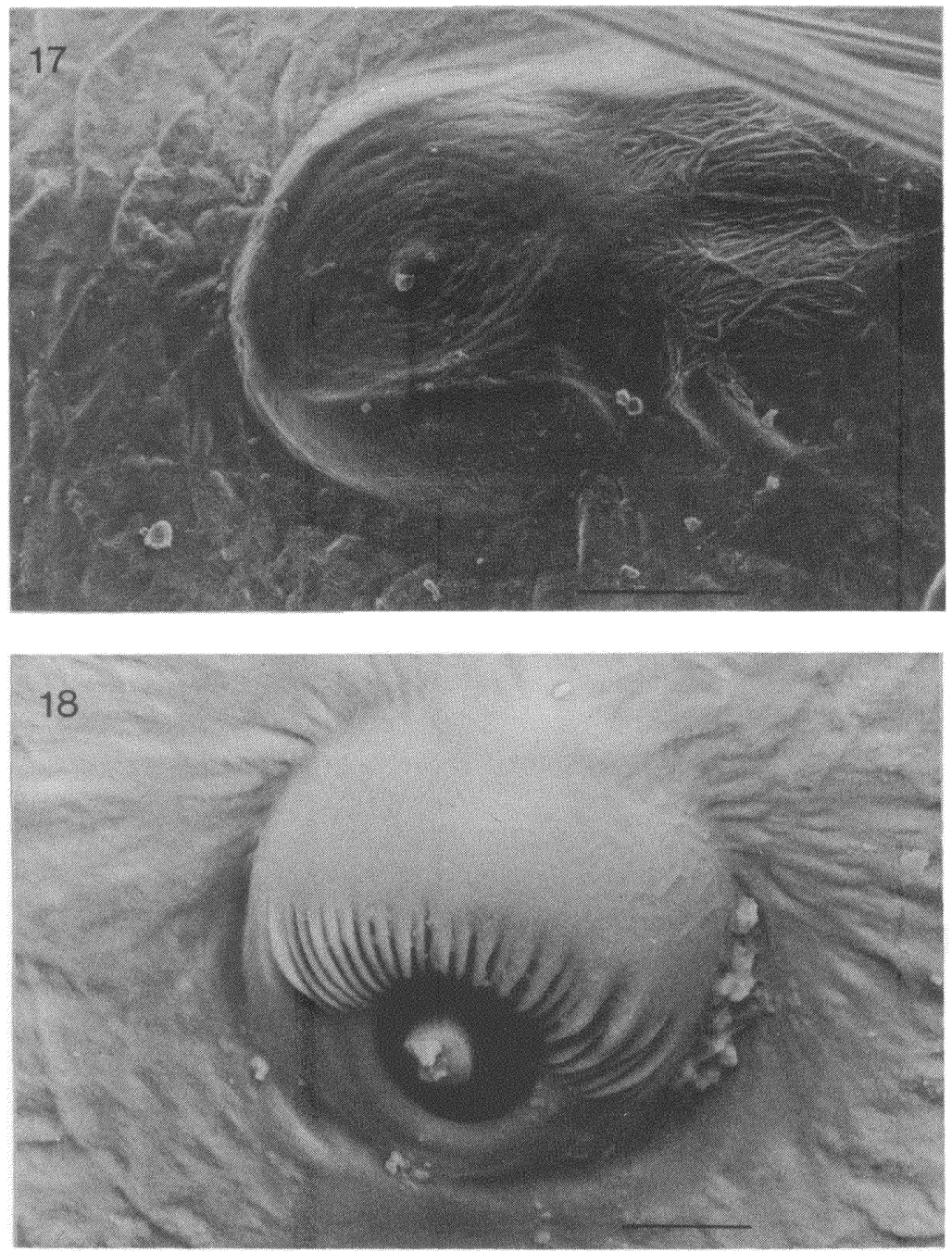

Figures 17, 18. Scanning electron microscope photographs, $T$. lowryi. Fig. 17. Tarsal organ. Fig. 18. Trichobothrial base. Scale bars $=10 \mu \mathrm{m}$. 
about $4, p$ about 6 (lost). Leg III, tarsus 0 , metatarsus $v$ about 10 (some lost), d about 5, p 6, r 4, tibia v about 10 (some lost), d 3, p 6, r about 4, patella p 2 (lost), r about 3, femur rd 4, p 9, r at least 4. Leg IV, tarsus $v$ with long bristles, metatarsus $v$ about $13, d$ about $5, p$ about $8, r 4$, tibia v about $7, d$ about $4, p$ about $7, r 6$, patella $p$ about $3, r$ ?, femur $d 4$ or $5, p$ about $9, r$ about 5 . Trichobothria generally lost, appear to have been less numerous than in most Australian diplurines. Tarsal claws all with double row of long and needle-like teeth (up to 9 or more in each row); inner rows of teeth begin distally to base of outer rows.

\section{Remarks}

The tarsal "spines" referred to by Main (1969) are not comparable to the usual heavy spines found on diplurine legs and as for the above specimen would be better described as "bristles".

\section{ACKNOWLEDGEMENTS}

We are grateful to A. D. Davey who collected the male specimen of Troglodiplura. Support from the Australian Biological Resources Study programme to one of us (BYM) is acknowledged.

\section{SUMMARY}

A male specimen of the cavernicolous genus Troglodiplura is described. It is suggested that a tibial spur, previously considered unique to the Anamini has arisen independently in Troglodiplura. Close affinity with other Australian Diplurinae is not recognized.

\section{ReFERENCES Cited}

Aussi:ki:R, A. (1875) Zweiter Beitrag zur Kenntniss der Arachniden-Familie der Territelariae Thorell. (Migalidae Autor.). Verhandlungen der zoologischhotanischen Gessellschaft in Wien, 25, 125 206, plates 57.

FAcil, L. (1929) Sur quelques Araignees des grottes de l'Amerique du Nord et de Cuba. Bollettino del Lahoratorio di zoologia generale e agraria della $R$. Siuola superiore d'Agricollura in Portici, 22, 181187.

Gray, M. R. (1973) Cavernicolous spiders from the Nullarbor Plain and southwest Australia. Journal of the Australian Entomological Societ1; 12. 207221.

GkAY, M. R. (1981) A revision of the spider genus Baiami Lehtinen (Araneae, Amaurobioidea). Records of the Australian Museum, 33, 779802.

(il:kTsc'll, W. J. (1971) A report on some Mexican cave spiders. Association for Mexican Cave Studies Bulletin, 4, 47 III. 
Gertscil, W. J. (1973) A report on cave spiders from Mexico and Central America. Association for Mexican Cave Studies Bulletin, 5, 141163.

Gistsc'H, W. J. (1982) The troglobitic mygalomorphs of the Americas (Arachnida, Araneae). Association for Mexican Cave Studies Bulletin, 8, 79.94.

MAiN, B. Y. (1969) A blind mygalomorph spider from a Nullarbor Plain cave. Journal of the Royal Society of Western Australia, 52, 9-11.

Main, B. Y. (1972) The mygalomorph spider genus Stanwellia Rainbow and Pulleine (Dipluridae) and its relationship to Aname Koch and certain other diplurine genera. Journal of the Rolal Society of Western Australia, 55, 100114.

MaiN, B. Y. (1975) The citrine spider: a new genus of trapdoor spider Mygalomorphae: Dipluridae). The Western Australian Naturalist, 13, 73-78.

Main, B. Y. (1976) Spiders. Collins, Sydney.

MAIN, B. Y. (1981) Eco-evolutionary radiation of mygalomorph spiders in Australia. in Keast, A. (ed.), Ecological hiogeography in Australia. Junk, The Hague.

MAIN, B. Y. (1982a) Notes on the revised taxonomic position of the Black Wishbone Spider Dekana diversicolor Hogg (Mygalomorphae: Dipluridae) Journal of the Rorlal Societ! of Western Australia, 65. 2529.

MaIN, B. Y. (1982b) Further studies on the systematics of Australian Diplurinae (Araneae: Mygalomorphae. Dipluridae): the taxonomic status of Proshermacha Simon and Chenistonia tepperi Hogg. Australian entomological Magazine, 8. 8388.

MAIN, B. Y. (1982c) Adaptations to arid habitats by mygalomorph spiders, Paper 31 in Barker, W. R. and Greenslade. P. J. M. (eds) Evolution of the Flora and Fauna of Arid Australia. Peacock Publications, Frewville, South Australia.

Main, B. Y. (1983a) Systematics of the trapdoor spider genus Homogona Rainbow (Mygalomorphae: Ctenizidae: Homogoninae). Journal of the Australian entomological Society: 22.8192.

MAIN, B. Y. (1983b) Further studies of the systematics of Australian Diplurinae (Chelicerata: Mygalomorphae: Dipluridae): Two new genera from south western Australia. Journal of Natural History, 17, 923-949.

MAIN, B. Y. (in press a) Further studies on the systematics of ctenizid trapdoor spiders: A review of the Australian genera (Araneae: Mygalomorphae: Ctenizidae). Australian Journal of Zoolog!: Supplementary Series.

MAIN, B. Y. (in press b). Further studies on Australian Diplurinae: A review of the genera of the Teylini (Araneae: Mygalomorphae: Dipluridae). Australian Journal of Zoology, 33(5).

MAin, B. Y. AND MAsc(ord, R. (1971) A new genus of diplurid spider (Araneae: Mygalomorphae) from New South Wales. The Journal of the entomological Societ! of Australia (N.S.W.), 6, 2430.

RAvin, R. J. (1979) Systematics of the mygalomorph spider genus Masteria (Masteriinac: Dipluridae: Arachnida). Australian Journal of Zoolog!l, 27. 623636.

RAVI:N, R.J. (1981) A review of the Australian genera of the mygalomorph spider subfamily Diplurinae (Dipluridae: Chelicerata). Australian Journal of Zoolog!: 29. 321363.

RAvin, R. J. (1984) A new diplurid genus from Eastern Australia and a related Aname species (Diplurinae: Dipluridae: Araneae). Australian Journal of Zoology: Supplementary Series, No. 96, 151. 
Simon, E. (1892) Arachnides des îles Philippines in Raffray, A., I. Bolivar and

Simon, E., Etude sur les Arthropodes cavernicoles de l'île Luzon. Annales de la Société entomologique de France, 61, 35-52.

Smiti, H. M. (1983). More on allotypes, S! sstematic Zoolog!r, 32, 454-455. 

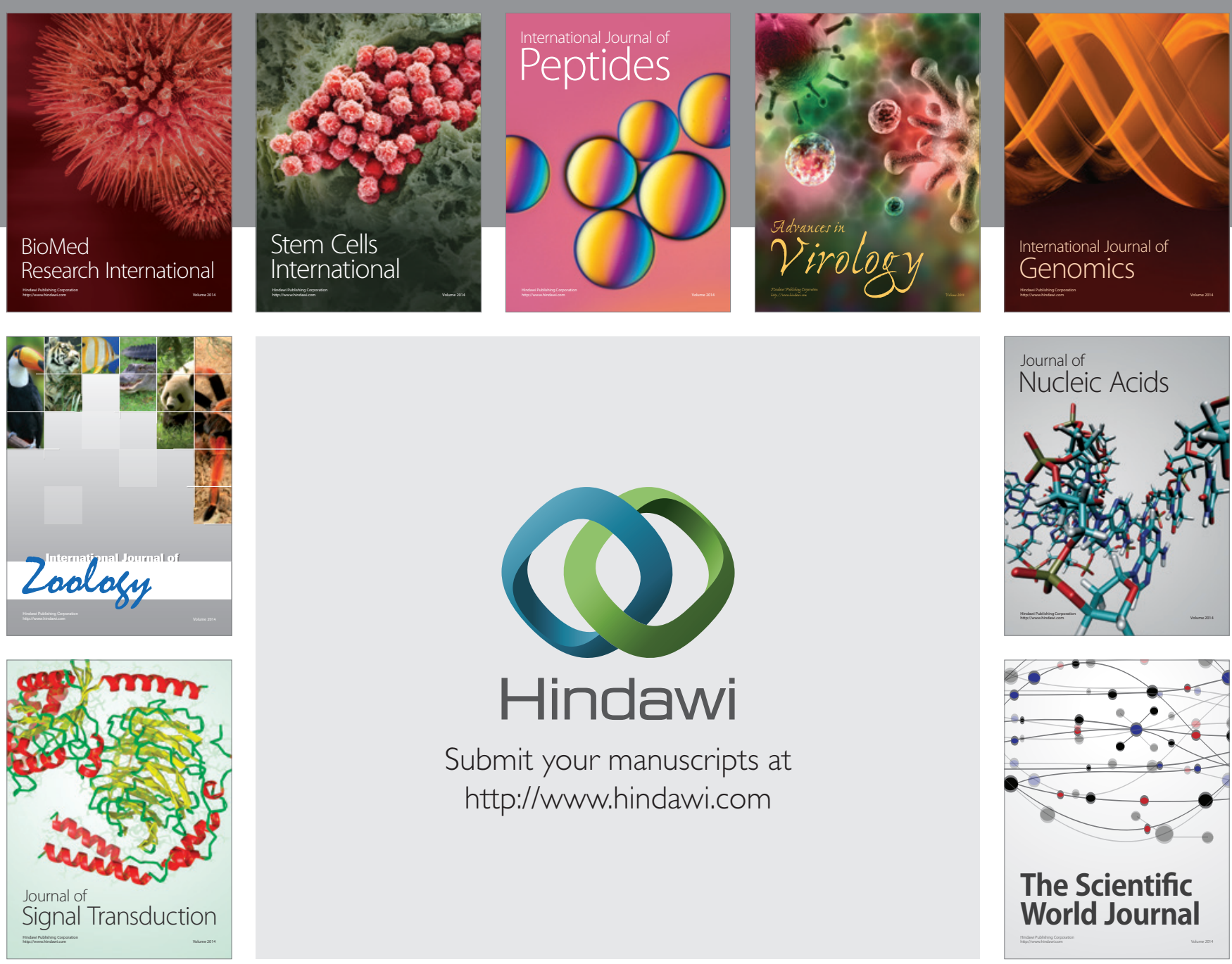

Submit your manuscripts at

http://www.hindawi.com
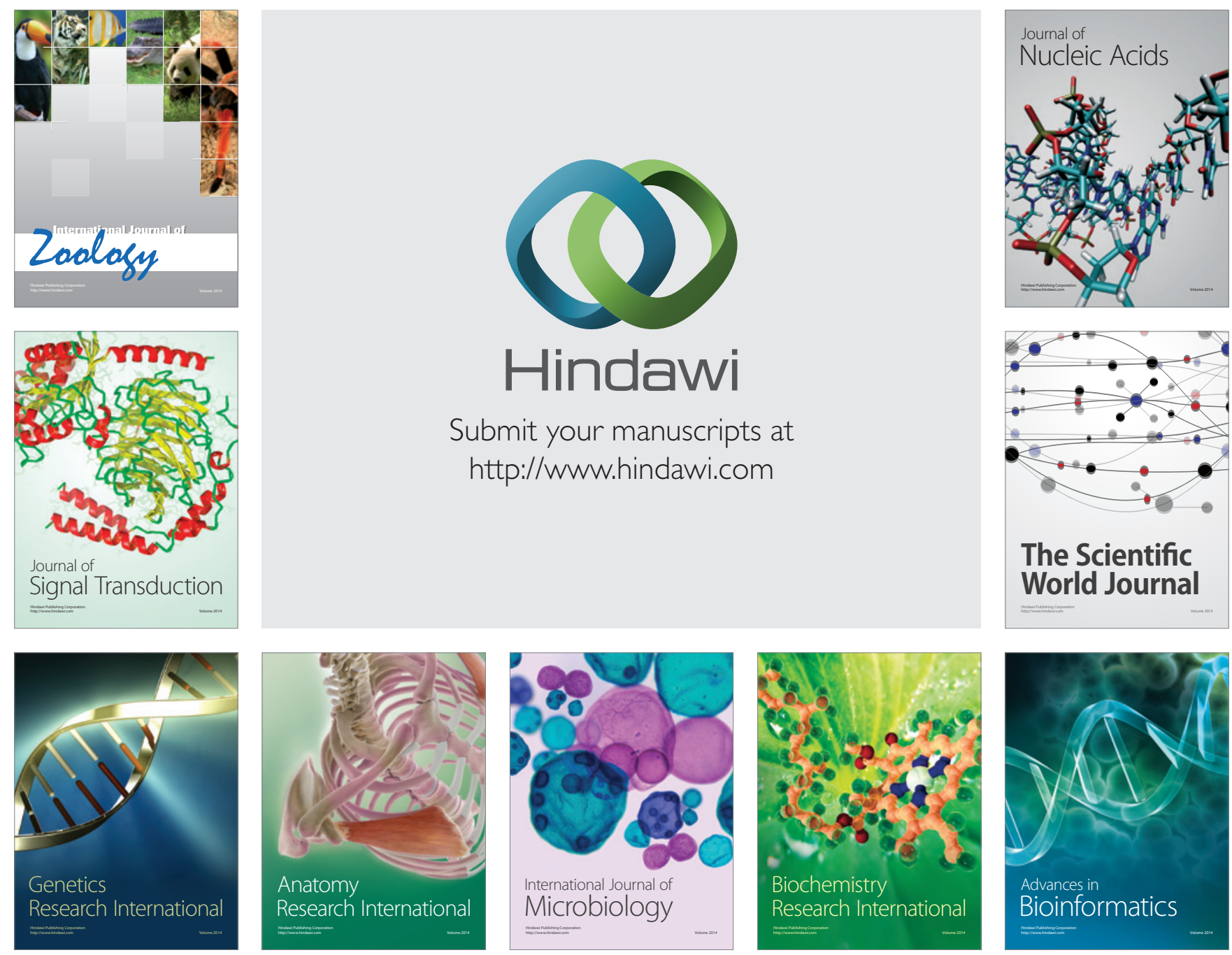

The Scientific World Journal
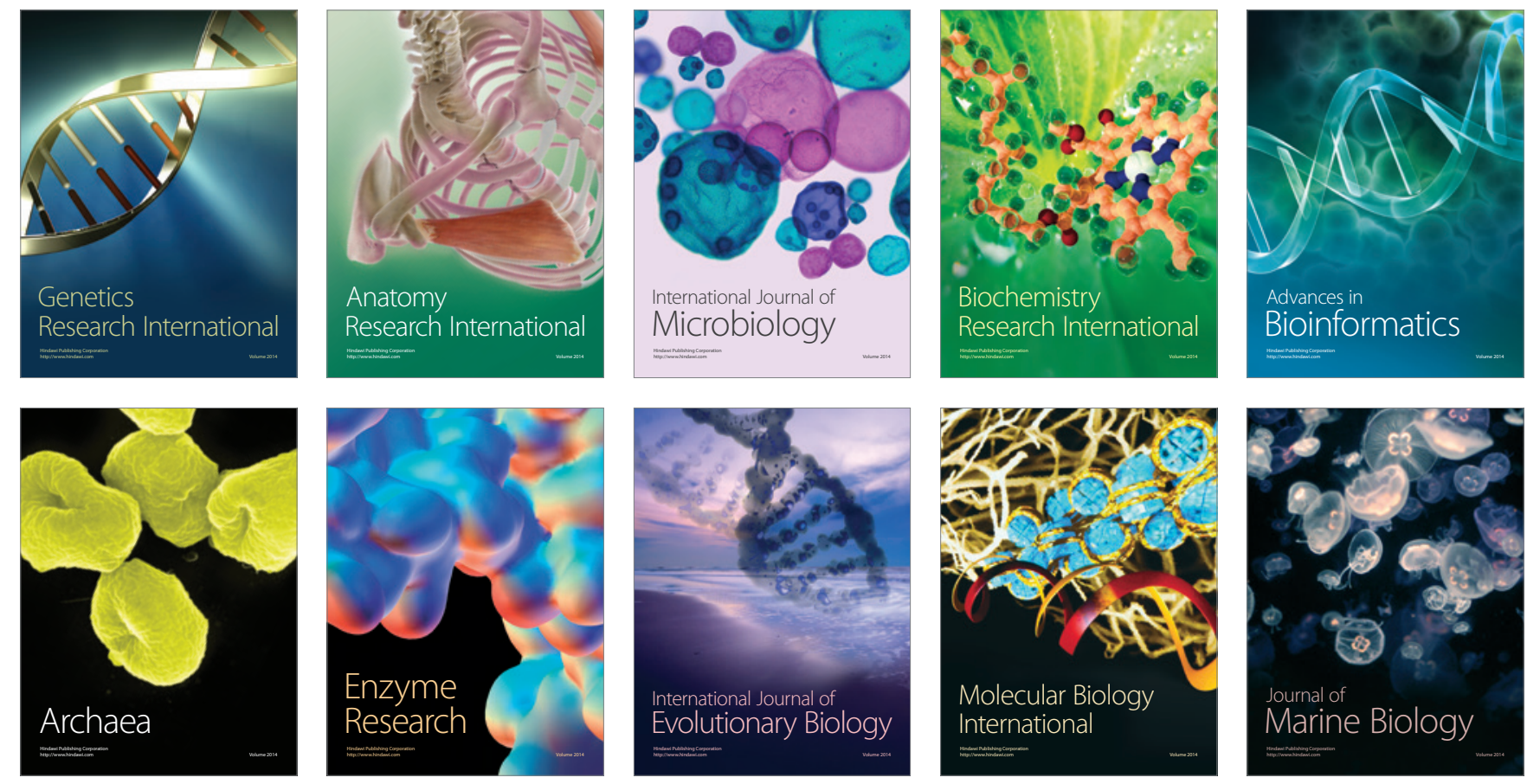